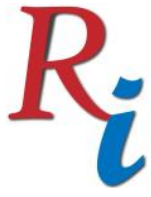

Asia Proceedings of Social Sciences

(APSS)

www.readersinsight.net/APSS

\title{
INTEGRATION OF PRODUCT AND PROCESS APPROACHES IN ESL CLASSROOMS
}

\section{Sarala Thulasi Palpanadan ${ }^{\star}$}

Center for Language Study

Universiti Tun Hussein Onn Malaysia

Malaysia

sarala@uthm.edu.my

\section{Venosha Ravana}

Faculty of Language and Linguistics

University Malaya

Malaysia

venosharavana@gmail.com

*Corrosponding author's Email: sarala@uthm.edu.my

Peer-review under responsibility of 4th Asia International Multidisciplinary Conference 2020 Scientific Committee http://connectingasia.org/scientific-committee/

() 2020 Published by Readers Insight Publisher, lat 306 Savoy Residencia, Block 3 F11/1,44000 Islamabad. Pakistan,

editor@readersinsight.net

This is an open access article under the CC BY-NC-ND license (http://creativecommons.org/licenses/by-nc-nd/4.0/). 


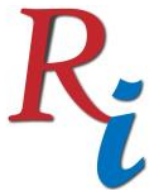

\section{Asia Proceedings of Social Sciences (APSS) \\ www.readersinsight.net/APSS}

\section{A b s t r a c t}

English as a second language (ESL) writing instructions demand a great deal of the teachers' time and effort to prepare adequate writing lessons for their students. Teachers have to decide on the right approach to be selected as the instructional method to enhance students' writing ability. Thus, this study investigates the preferred teaching practices (between the product and process approach) of 10 pre-service teachers' in teaching writing and the effects on students' written texts. The data were collected from observations, semi-structured interviews and students' written texts. The data from the observation checklists were analyzed using Rasch Measurement Model which validated the study with a high value of alpha Cronbach (0.81). Thematic and textual analyses were conducted on participants' views and the students' written text respectively. The findings highlighted the pre-service teachers preferred to employ product approach as their main writing instruction where the students were found to prepare their written work based on the input provided to them. The students' written work with linguistic accuracy was mainly focused but the students did not show much creatively. Thus, this study recommends that teachers should integrate process approach strategies into their writing instructions to enhance students' writing more profoundly in the future.

\section{Research High I ight s}

1. The challenges of teaching writing in ESL classrooms.

2. Pre-service teachers' preferred teaching approaches to teach writing to students.

3. The effects of the selected approached employed by the pre-service teachers on the students' written texts.

\section{Research Objectives}

This study aims to explore the writing instructions practiced by English as a Second Language (ESL) teachers who strive to get students to write effectively. Many ESL teachers face challenges to teach English in terms of students' language proficiency, time constraint, pedagogical factors, institutional demands and many more (Foo, 2007; Akinwamide \& Kolade, 2012; Hasim \& Zuwati, 2014). However, they had to meet the demand of the educational institutions to produce results in terms of students' passing rate and grades (Lie, 2008). This scenario becomes a huge problem in ESL classrooms. Thus, the preferred writing instruction used by the selected pre-service teachers were studied in terms of practicing the product and process approach. This study was conducted to achieve two research objectives: (i) to identify the preferred approaches employed by the pre-service teachers in their writing lessons in the ESL classrooms and (ii) to identify the effects of the pre-service teachers' teaching practices on the students' written tasks. This study was significant as the real scenario of the writing 


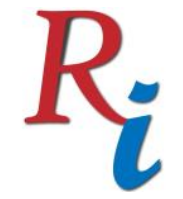

\section{Asia Proceedings of Social Sciences}

(APSS)

www.readersinsight.net/APSS

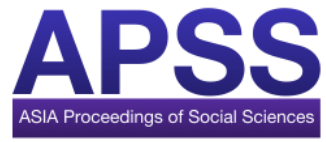

lessons could be investigated so that effective writing approaches and strategies could be recommended to be brought into writing practices in producing more independent and effective writers.

\section{Methodology}

This reaserch is a multiple case study which aimed at identifying the preferrred writing instructions of the selected pre-service teachers and the effects of their teaching approaches towards the students' written tasks. The study employed a mixed method design. Data for the study were collected through observations, semi-structured interview and written documentations (students' written texts). 10 pre-service teachers who taught in a particular state of Malaysian primary schools were selected as participants through purposive sampling technique. Each participants' writing lessons were recorded (five observations per participant). Data from the observations were collected using observation checklist and taking field notes. The observation checklist was validated descriptively using Rasch Measurement Model. Meanwhile, data from the from the semi-structured interviews were transcribed and analyzed thematically. The students' written texts were analyzed to identify the effects of the teaching approaches and strategies practised by the participants on the students' written products.

\section{Results}

The observation checklist used in the study was analyzed using Rasch Measurement Model. The values for item reliability and person reliability were 0.98 (excellent) and 0.81 (good) respectively (Fisher, 2007). Moreover, the reading of alpha Cronbach was 0.86 which highlighted the reliability of this study. The observations conducted during the pre-service teachers' writing lessons showed that the majority of them employed product approach to teach writing during the presentation $(60 \%)$, practice $(100 \%)$ and production $(100 \%)$ stages. Thus, the overall preferred teaching practice employed by the pre-service teachers was the product approach. The observation analysis was triangulated with the the views shared by the preservice teachers in the semi-structured interviews for selecting the product-oriented approach dominantly in their teaching practices. The participants shared that their main targets were mainly to provide sufficient input for the students to write. Subsequently, a majority of 80 percent of the participants' students were found to have employed product approach in preparing their final written work which were very identical to the participants' input. The output of the students was observed to be almost perfect without much errors in terms of language knowledge such as spelling, punctuation and sentence structure.

\section{Findings}

The study highlighted that most of the participants felt obliged in providing input during the writing lessons to help students to write well. They spent more time during the presentation 


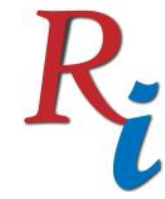

\section{Asia Proceedings of Social Sciences}

(APSS)

www.readersinsight.net/APSS

and practice stages to teach language components and less time on production stage (for inclass writing). Thus, this study suggests that teachers should allocate more time for production stage. This planning can help teachers to integrate free writing strategy of the product approach and several strategies of the process approach such as the planning, drafting and editing before producing the final piece of writing to enhance students' writing ability.

\section{Acknowledgement}

This paper is supported by University Tun Hussein Onn Malaysian (Registrar Office)

\section{References}

Akinwamide, \& Kolade, T. (2012). The Influence of Process Approach on English as Second Language Students' Performances in Essay Writing. ELT Journal., 5(3), 16-29.

Fisher, W. P. (2007). Rating Scale Instrument Quality Criteria. Retrieved April 11, 2020, from https://www.rasch.org/rmt/rmt211m.htm

Foo, T. C. V. (2007). The Effects of the process-genre approach to writing instruction on the expository essays of ESL students in a Malaysian secondary school. kuala Lumpur, Malaysia.

Hasim, Z., \& Zuwati, H. (2014). An Integration of a Process Approach and Formative Assessment into the Development of Teaching and Learning of ESL Writing in a Malaysian University: A Sociocultural Perspective. University of Waikato.

Lie, K. Y. (2008). Language, culture and literacy: Meaning-making in global context.

Universiti Kebangsaan Malaysia.

Author's Biography

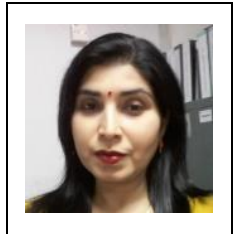

Dr Sarala Thulasi Palpanadan is an English Language lecturer at Universiti Tun Hussein Onn Malaysia (UTHM), teaching undergraduate and postgraduate students. She specialized in TESL, teacher education and second language acquisition. She has published many papers in reputable journals and authored several books and book chapters. She has conducted various programs in relation to ESL and ELT to language teachers and students.

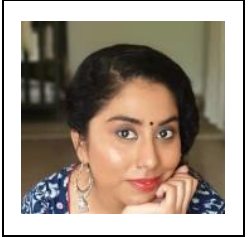

Ms Venosha Ravana is a full-time postgraduate student from the Faculty of Languages and Linguistics, University Malaya. While her areas of interests are English for Specific Purposes (ESP) and curriculum design, she has some publications in a few reputable journals in the areas of English language studies and teacher training and development. 